\title{
ANALISIS PENDISTRIBUSIAN BANDWIDTH PADA VIDEO STREAMING DENGAN METODE UNICAST DAN MULTICAST PADA TEKNOLOGI GIGABIT PASSIVE OPTICAL NETWORK
}

\author{
Nandi $^{1}$ \\ Fakultas Komputer, Universitas \\ Muhammad Husni Thamrin \\ Email:nandikudit@gmail.com
}

\author{
Tata Sutabri ${ }^{2}$ \\ Fakultas Komputer, Universitas \\ Muhammad Husni Thamrin \\ E-mail:tata.sutabri@gmail.com
}

\author{
Muhammad Ridwan ${ }^{3}$ \\ Fakultas Komputer, Universitas \\ Muhammad Husni Thamrin \\ E-mail: jundi79@gmail.com
}

\begin{abstract}
Abstrak
Bandwidth tidak bisa dipsahkan dari yang namanya internet, dengan adanya internet kita dapat mengakses content-conten online sebagai kebutuhan dalam mencari informasi maupun hiburan yang salah satunya adalah video live streaming atau live $T V$, dalam pengaplikasian video live streaming atau live $T V$ membutuhkan bandwidth yang cukup besar. Tentu dengan ini penulis akan melakukan sebuah penelitian untuk mengetahui kebutuhan bandwidth
\end{abstract}

\section{PENDAHULUAN}

Jaringan internet yang semakin berkembang dan sudah mulai meluas di masyarakat sangat memudahkan untuk mendapatkan informasi atau hiburan melalui internet khusus nya pada video streaming, bahkah saat ini teknologi yang sedang berkembang di masyarakat adalah layanan Internet Protocol Television (IPTV).

Dalam pengaplikasian video streaming membutuhkan bandwidth yang cukup besar terlebih dalam video streaming biasanya di akses oleh banyak orang dalam waktu bersamaan sehingkan membuat kualitas gambar menjadi tidak bagus bahkan akan terjadi buffer (jeda waktu) dalam proses streaming.

Maka dari itu penulis akan melakukan analisis atau penelitian untuk memanfaatkan bandwidth secara optimal sehingga dapat meminimalisir penggunaan atau pengeluaran bandwidth yang sangat besar dengan mengunkan metode unicast dan multicast sebagai media pengiriaman data pada teknologi yang berbasis Gigabit Passive Optical Network (GPON)

\section{LANDASAN TEORI}

\subsection{Pengertian Bandwidth}

Bandwidth adalah besaran yang menunjukan seberapa banyak data yang dapat dilewatkan dalam koneksi melalui sebuah network. Istilah ini berasal dari bidang teknik listrik, dimana bandwidth yang menunjukan total jarak atau berkisar antara tertinggi dan terendah sinyal pada saluran komunikasi (band) banyak orang awam yang kadang menyamakan arti istilah bandwidth dan data transfer. Bandwidth sendiri menunjukan volume data yang dapat di transfer per-unit waktu. Sedangkan data transfer adalah ukuran lalu lintas data dari website. Lebih mudah kalau dikatakan bahwa bandwidth adalah rate dari data transfer [2].

\subsubsection{Jenis - Jenis Bandwidth}

untuk video streaming dengan metode pengiriman data multicast dan unicast pada teknologi gigabit passive optical network (GPON). Kebutuhan bandwidth meningkat pada metode unicast ketika bertambah jumlah client ( 3 client) yang meng-akses video streaming dan bandwidth tidak ada kenaikan pada metode multicast ketika di akses oleh 3 client.

Kata Kunci: Bandwidth, Video Live Streaming, Unicast, Multicast, GPON

Terdapat 2 jenis bandwidth, diantaranya:

\section{Bandwidth Analog}

Bandwidth analog adalah rentang antara frekuensi terendah dengan frekuensi tertinggi yang digunakan pada transmisi signal radio dalam satuan Hertz (Hz).

\section{Bandwidth Digital}

Bandwidth digital adalah banyaknya data (bit) yang dapat dikirimkan dan diterima dalam 1 detik. Satuan yang biasa digunakan adalah bits, Byte, Kilo, Mega, Giga. 1bit mewakili data yang dikirim dalam bentuk digital (1 (on) dan 0 (off).

\subsubsection{Manajemen Bandwidth}

Manajemen bandwidth adalah suatu metode yang dapat digunakan untuk manajemen dan mengoptimalkan sebagai jenis jaringan dengan menerapkan layanan Quality of Service (QoS) untuk menetapkan tipe - tipe lalu lintas jaringan. Sedangkan QoS adalah kemampuan untuk menggambarkan suatu tingkatan pencapaian didalam suatu sitem komunikasi data.

\subsection{Konsep Dasar Video Streaming}

Agil S (2010:1) Streaming adalah sebuah teknologi untuk memainkan file video atau audio secara langsung ataupun dengan pre-record dari sebuah server (web server). Dengan kata lain, file video ataupun audio yang terletak dalam sebuah server dapat secara langsung dijalankan pada UE (User Equipment) sesaat setelah ada permintaan dari user, sehingga proses running aplikasi yang di download berupa waktu yang lama dapat dihindari tanpa harus melakukan proses penyimpanan terlebih dahulu. Saat file video atau audio di stream, akan berbentuk seuah 
buffer dikomputer client, dan data video atau audio tersebut akan mulai di download kedalam buffer yang telah terbentuk pada mesin client.

\subsubsection{Protocol Video Streaming}

Protokol adalah aturan - aturan yang diterapkan untuk teknologi tertentu, protokol pada teknologi streaming yang digunakan untuk membawa pesan paket dan komunikasi terjadi melalui protokol tersebut. Berikut beberapa protokol yang digunakan dalam teknologi video streaming:

\section{User Datagram Protocol (UDP):} Merupakan sebuah protokol internet yang mengutamakan kecepatan data, protokol ini biasanya digunakan untuk streaming video atau fasilitas realtime yang lain. Oleh karena itu pada UDP tidak memerlukan peroses setup koneksi terlebih dahulu karena hal tersebut dapat menyebabkan adanya tambahan delay, selain itu protokol ini termasuk dalam protocol yang sederhana, artinya antara penerima dan pengirim tidak perlu menjaga session atau status koneksi, ukuran header nya juga sederhana. UDP tidak memerlukan Congestion Control (kontrol kemacetan) pada koneksinya. Maksudnya adalah, UDP dapat mengirimkan per segmen tanpa dipengaruhi oleh kesibukan jaringan.

\section{Real-time Transport Protocol (RTP):} Sebuah paket dalam format UDP dan perangkat konversi yang menyediakan fungsi jaringan transportasi end-to-end, cocok untuk aplikasi transmisi data real-time seperti video, audio atau data simulasi melalui layanan jaringan multicast dan unicast.

\section{Real-time Control Protocol (RTCP):} Protokol yang bekerja sama dengan RTP. Paket kontrol RTCP secara berkala dikirimkan oleh masing - masing paket dalam sesi RTP untuk semua paket lainnya. RTCP digunakan untuk mengkontrol kinerja dan untuk tujuan diagnostik.

4. Real-time Streaming Protocol (RTSP): Sebuah protokol level aplikasi untuk kontrol atas pengiriman data dengan sifat real-time. RTSP menyediakan rangka extensible untuk mengaktifkan kendali pada pengiriman data real-time, seperti vidio dan audio dengan menggunakan Transmission Control Protocol (TCP) atau User Datagram Protocol (UDP).

\subsection{Gigabit Passive Optical Network (GPON)}

Gigabit Passive Optical Network (GPON) merupakan salah satu teknologi yang dikembangkan oleh ITU-T via G.984 dan hingga kini bersaing dengan Gigabit Ethernet PON (GEPON), yaitu PON versi IEEE yang berbasiskan teknologi ethernet. GPON mempunyain dominansi pasar yang lebih tinggi dan rollout lebih cepat dibanding penetrasi GEPON. Standar G.984 mendukung bit rate yang lebih tinggi, perbaikan keamanan, dan pilihan protokol layer 2 (ATM, GEM, atau Ethernet) [3].

GPON maupun GEPON menggunakan serat optik sebagai media transmisi, satu perangkat akan diletakan pada sentral dan kemudian akan mendistribusikan trafik triple play (suara atau voip, multimedia atau digital pay $\mathrm{TV}$, dan data atau internet) hanya melalui 1 core kebel optik sebagai media transmisi disisi subscriber atau pelanggan. Yang menjadi ciri khas dari teknologi ini dibanding teknologi optik lainnya semacam SDH adalah teknik distribusi trafik dilakukan secara pasif dari sentral hingga ke arah pelanggan akan didistribusikan menggunakan splitter pasif $(1: 2,1: 4,1: 16,1: 32$, $1: 64)$.

Teknologi GPON menggunakan Time Division Multiple Access (TDMA) sebagai teknik multiple access upstream dengan data rate sebesar 1.2 Gbps dan menggunakan broadcast kearah downstream dengan data rate 2.5 Gbps. Model paketisasi data menggunakan GEM (GPON Encapsulation Methode) atau ATM cell untuk membawa layanan TDM dan packet based. GPON memiliki efisiensi bandwidth yang lebih baik yaitu 93\% dibandingkan dengan BPON hanya $70 \%$.

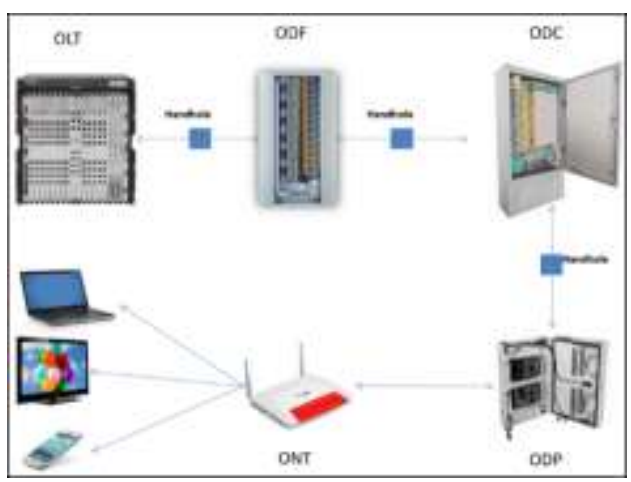

Gambar 1. Komponen Jaringan GPON

\subsection{Prinsip Kerja GPON}

GPON merupaka teknologi FTTx yang dapat mengirimkan informasi sampai ke pelanggan menggunakan kebel optik. Ketika data atau sinyal dikirimkan dari OLT, maka ada bagian yang bernama splitter yang berfungsi untuk memungkinkan serat optik tunggal dapat mengirim ke berbagai ONU. 
ONU sendiri yanga akan memberikan data data atau sinyal yang diinginkan pelangan.

Pada prinsipnya, PON adalah sistem point to multipoint yang menggunakan spitter sebagai pembagi jaringannya. Arsitektur sistem GPON berdasarkan pada TDM (Time Division Multiplexing) sehingga mengdukung layanan T1, E1 dan DS3.Optik) [3].

\subsection{Komponen - Komponen GPON}

Komponen - komponen dalam teknologi GPON yang umum digunakan, yaitu sebagai berikut:

\section{Network Management System (NMS)}

Network Management System (NMS) merupakan perangkat lunak yang berfungsi untuk mengontrol atau memonitoring dan mengkonfirgurasi perangkat GPON. Letak NMS ini bersamaan di dekat OLT namun berbeda ruangan, konfiguarasi yang dapat dilakukan oleh NMS adalah OLT dan ONT, selain itu NMS dapat mengatur layanan GPON seperti POTS, VoIP dan IPTV. NMS ini menggunakan platform windows dan bersifat GUI (Graffic Unit Interface) maupun command line.

\section{Optical Line Terminal (OLT)}

Optical Line Terminal (OLT) menyediakan interface antara PON dengan penyedia layanan (Service Provider) data, video dan jaringan telepon. Bagian ini akan membuat link ke sistem operasi penyedia layanan melalui Network Management System (NMS).

\section{Optical Distribution Cabinet (ODC)}

Optical Distribution Cabinet (ODC) adalah jaringan optik antara perangkat OLT sampai perangkat ODC, ODC menyediakan sarana transmisi optik dari OLT terhadap pengguna dan sebaliknya, komponen ini menggunakan komponen pasif.

\section{Optical Distribution Pack (ODP)}

Instalasi atau transmisi yang bagus dari serat adalah persyaratan utama untuk menjamin kemampuan transmisi pada kabel transmisi, syarat utama ODP adalah: a) ODP dapat diubah tanpa mengganggu kabel yang sudah terpasang dengan Cara melebihkan kabel serat optik beberapa meter.

b) Setiap ODP harus mempunyai ruang untuk memuat splitter.

c) Setiap ODP harus memiliki penutup depan untuk melindungi orang dari cahaya laser yang langsung keluar dari ujung serat optik.

d) ODP harus mempunyai ruang untuk memuat dan memandu kabel serat optik.

\section{Optical Splitter}

Splitter merupakan perangkat yang membagi daya optik menjadi $\mathrm{N}$ jalur terpisah menuju pelanggan. Sebagai penghubung antara OLT dengan ONU, berfungsi untuk mentransmisikan sinyal input optik arah downlink menuju port multi output dan bisa membagi satu serat optik kedalam multi user dimana bandwidth dari serat tersebut dibagi-bagi. Untuk arah uplink, me-multiplexing kanal-kanal sinyal optik ONU menuju satu serat optik.

Design pembagi daya dengan rasio pembagi juga munkin dan terdapat lebih dari satu splitter dalam jalur tertentu tergantung penerapan nya. Jumlah jalur yang terbagi bisa beragam dari 2 hingga 64, tetapi biasanya berjumlah 8,16 , dan 32 .

\section{Optical Network Termination (ONT)}

Optical Network Termination (ONT) menyediakan interface antara jaringan optik dengan pelanggan, sinyal optik yang ditransmikan melalui ODN diubah oleh ONT menjadi sinyal elektrik yang diperlukan untuk service pelanggan. Pada arsitektur FTTH, ONT diletakan di sisi pelanggan.

\section{$2.5 \quad$ Multicast}

Agil S (2010:1) Transmisi multicast adalah dari satu pengirim ke banyak penerima. Klien akan mendapat aliran video yang sama. Total bandwidth yang dibutuhkan akan tetap sama dan tidak tergantung dengan banyak nya klien yang menerima streaming tersebut. Sebagai contoh, terdapat 10 orang penerima yang meminta transmisi sebesar $100 \mathrm{~kb} / \mathrm{s}$, maka total bandwidth yang dibutuhkan tetap $100 \mathrm{~kb} / \mathrm{s}$. transmisi seperti inilah yang banyak digunakan didunia maya saat ini. Termasuk di Indonesia yang masih mempunyai kecepatan internet rata-rata $100 \mathrm{~kb} / \mathrm{s}$ atau kecepatan broadband biasa. 


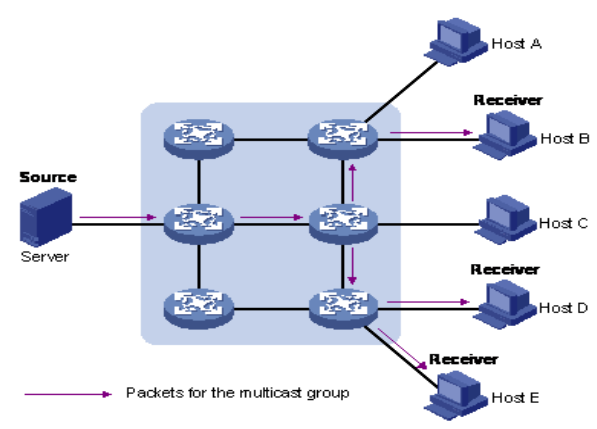

Gambar 2. Multicast

\section{$2.6 \quad$ Unicast}

Agil S (2010:1) Transmisi unicast merupakan transmisi informasi yang dilakukan dari satu pengirim ke satu penerima. Transmisi unicast sering disebut transmisi point to point. Setiap penerima (klien) akan menerima aliran video yang berbeda walaupun menampilkan film yang sama. Artinya kelancaran video yang diterima oleh klien bergantung pada kecepatan download computer klien. Sebagi contoh, terdapat 5 klien yang menonton video streaming kita dengan transmisi sebesar $100 \mathrm{~kb} / \mathrm{ps}$, maka total bandwidth yang digunakan adalah sebesar $5 \times 100 \mathrm{~kb}=500 \mathrm{~kb}$, keuntungan klien adalah mendapatkan kualitas gambar video dan audio yang real time dan renggang waktu menunggu ketertinggalan sangat sedikit.

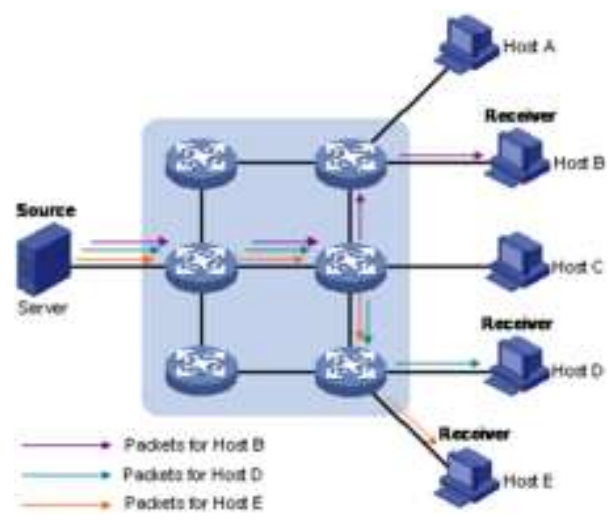

Gambar 3. Unicast

\section{3}

\section{METODE PENELITIAN}

\subsection{Topologi yang digunakan}

Dalam melakukan pengujian ini topologi jaringan menggunakan teknologi Gigabit Passive Optical Network (GPON) yang terdiri dari 1 unit PC (Personal Computer) yang berperan sebagai server, 1 unit Switch, 1 unit OLT (merk Huawei), 1 unit Splitter 1:8, 1 unit ONT (merk Huawei) atau access point, dan 3 unit laptop yang berperan sebagai client.

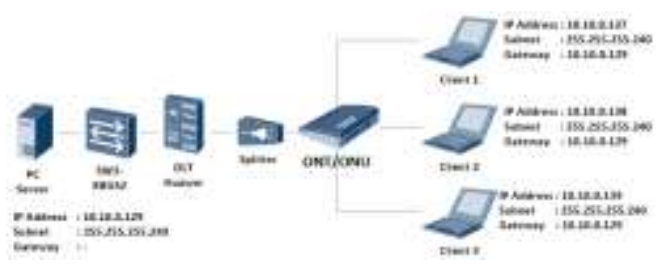

Gambar 4. Topologi Pengujian

Dalam topologi diatas penulisn menggunakan infrastruktur yang ada di PT. Indosat Mega Media, dan dapat dilihat bahwa jaringan tersebut adalah jaringan point-to-point (PTP), dikarenakan perangkat yang satu dengan yang lainnya langsung terhubung, sehingga bandwidth yang dihasilkan merupakan data actual dari pengujian ini, dimana content yang di broadcast oleh server langsung di access oleh client.

\subsection{Hardware yang Digunakan}

Adapun Hardware yang digunakan dalam jaringan Gigabit Passive Optical Network (GPON), khusunya dalam pengujian ini diantara nya adalah:

\subsubsection{Optical Line Terminal (OLT)}

Optical Line Terminal (OLT) Merupakan hardware utama dalam jaringan Gigabit Passive Optical Network (GPON) yang terinstal di central office atau data center sebagai titik akhir dari sebuah jaringan fiber optik pasif dan berfungsi untuk merubah sinyal listrik yang digunakan oleh penyedia layanan dan sinyal optik yang digunakan oleh jaringan fiber optik pasif. Dengan Spesifikasi sebagai berikut:

Tabel 1. Spesifikasi OLT MA5600T

\begin{tabular}{|c|c|}
\hline Merk & \begin{tabular}{|l|l|} 
Huawei \\
\end{tabular} \\
\hline Type & MA5600T \\
\hline Dimensions (WxDxH mm) & $490 \times 275.8 \times 447.2$ \\
\hline \begin{tabular}{|l|} 
Weight \\
\end{tabular} & $33 \mathrm{~kg}$ \\
\hline Operating Environment & $\begin{array}{l}\text { Temperature: }-25^{\circ} \mathrm{C} \text { to }+55^{\circ} \mathrm{C} \\
\text { Relative Humidity }(\mathrm{RH}): 5 \% \text { to } 95 \%\end{array}$ \\
\hline Power Parameter & $\begin{array}{l}\text { Supports }-48 \mathrm{~V} \mathrm{DC} \text { power input, dual-power supply protection, } \\
\text { and working voltage range of }-38.4 \mathrm{~V} \text { to }-72 \mathrm{~V} \text {. }\end{array}$ \\
\hline Cabinet & $\begin{array}{l}\text { Indoor: N63E-22, N66E-18 } \\
\text { Outdoor: F01D500 }\end{array}$ \\
\hline Configuration & \begin{tabular}{|l|} 
control board: 2 \\
Service board: 16 \\
Universal Interface board: 1 \\
Upstream interface board: 2 \\
Power interface board: 2
\end{tabular} \\
\hline MTBF & $\approx 45$ years \\
\hline $\begin{array}{l}\text { Switching Capacity of the } \\
\text { Backplane Bus }\end{array}$ & $3.2 \mathrm{Tbit} / \mathrm{s}$ \\
\hline $\begin{array}{l}\text { Switching Capacity of the } \\
\text { Control Board }\end{array}$ & $\begin{array}{l}\text { SCUN/SCUK: } 480 \mathrm{Gbit} / \mathrm{s} \text { (Standby mode), 960Gbit/s (Load- } \\
\text { sharing mode) } \\
\text { SCUH: } 960 \mathrm{Gbit} / \mathrm{s} \text { (Standby mode), 1920Gbit/s (Load-sharing } \\
\text { mode) } 960 \mathrm{Gbit} / \mathrm{s}\end{array}$ \\
\hline Access Capacity & \begin{tabular}{|l|l|l|l|l}
$-128^{*} 10 \mathrm{G} G \mathrm{GPN}$ \\
$\cdot 256^{*} \mathrm{GPON}$ \\
$.768^{*} \mathrm{GE} / \mathrm{FE}$
\end{tabular} \\
\hline Maximum uplink port (GIU) & $\begin{array}{l}\cdot 4^{*} \mathrm{GE} \\
\cdot 4^{*} 10 \mathrm{GE}\end{array}$ \\
\hline
\end{tabular}

\subsubsection{Optical Network Terminal (ONT)}

Merupakan perangkat yang terinstal di sisi pelanggan atau bisa di sebut dengan access point, adapun spesifikasi untuk Optical Network Terminal (ONT) sebagai berikut:

Tabel 2. Spesifikasi ONT HG8245H 


\begin{tabular}{|l|l|}
\hline Merk & Huawei \\
\hline Type & HG8245H \\
\hline Dimensions (HxWxD) & $(176 \times 138.5 \times 28) \mathrm{mm}$ (without an external antenna) \\
\hline Weight & about $500 \mathrm{~g}$ \\
\hline Operating temperature & $0^{\circ} \mathrm{C}$ to $+40^{\circ} \mathrm{C}$ \\
\hline Operating humidity & $5 \% \mathrm{RH}$ to $95 \% \mathrm{RH}$ (non-condensing) \\
\hline Power adapter input & $100-240 \mathrm{~V} \mathrm{AC}, 50-60 \mathrm{~Hz}$ \\
\hline System power supply & $11-14 \mathrm{~V} \mathrm{DC}, 2 \mathrm{~A}$ \\
\hline Static power consumption & $5 \mathrm{~W}$ \\
\hline Maximum power consumption & $15.5 \mathrm{~W}$ \\
\hline Ports & 2POTS+4GE+Wi-Fi+USB \\
\hline Indicators & POWER/PON/LOS/LAN/TEL/USB/WLAN/WPS \\
\hline
\end{tabular}

\subsubsection{Personal Computer (PC) Server}

Personal Computer (PC) Server di gunakan sebagai server untuk penyimpanan atau pendistribusian video streaming, adapun spesifikasi sebagai berikut:

Tabel 3. Spesifikasi PC Server

\begin{tabular}{|l|l|}
\hline Merk & Zyrex \\
\hline Processor & Intel Core i3-4150 3.5GHz, 3mb Cache \\
\hline Operating System & Windows 7 Professional 64-bit \\
\hline Monitor & Zyrex LED 18.5 Inch \\
\hline Graphics & Intel $®$ HD Graphics \\
\hline Memory & 4GB DDR3. Max 16GB \\
\hline Storage & 500GB HDD SATA \\
\hline Dimensions (WxDx H) & $182 \times 380 x$ 53 mm \\
\hline Weight & $14 \mathrm{Kg}$ \\
\hline Daya / Power & $300 \mathrm{~W}$ \\
\hline Ethernet & $10 / 100 / 1000 \mathrm{Mbps}$ \\
\hline
\end{tabular}

\subsubsection{Laptop Client}

Laptop Client digunakan untuk meng-aksess video yang telah di stream oleh server dengan sepesifikasi sebagai berikut:

Tabel 4. Spesifikasi PC Client

\begin{tabular}{|c|c|}
\hline Merk & Lenovo \\
\hline Type & E450 \\
\hline Processor & Intel Core i5-5200U Processor (3M Cache, $2.2 \mathrm{GHz}$ ) \\
\hline Operating System & Windows 8.1 Pro 64-bit \\
\hline Display & $\begin{array}{l}\text { 14.0" HD (1366x768), anti-glare, } 200 \text { nits } \\
\text { 14.0" FHD (1920x1080), anti-glare, } 220 \text { nits }\end{array}$ \\
\hline Graphics & $\begin{array}{l}\text { Intel HD Graphics in processor only, or AMD } \\
\text { Radeon }^{\mathrm{TM}} \text { R7 M260 Graphics, 2GB Memory }\end{array}$ \\
\hline Memory & $8 \mathrm{~GB}$ DDR3 (upgradable up to $16 \mathrm{~GB}$ ) \\
\hline Storage & HDD: $500 \mathrm{~GB} 7200 \mathrm{rpm} / 1 \mathrm{~TB} 5400 \mathrm{rpm}$ \\
\hline Dimensions (WxDx H) & $339 \times 239 \times 24 \mathrm{~mm}$ \\
\hline Weight & Starting from $1.81 \mathrm{~kg}$ \\
\hline Case colour & Graphite Black \\
\hline Case material & PC/ABS plastic \\
\hline Battery & 6-cell Li-Ion battery $(47 \mathrm{Wh})$ \\
\hline Battery Life & Up to 9.0 hours (based on MobileMark2012) \\
\hline AC adaptor & \begin{tabular}{|l} 
Integrated: $45 \mathrm{~W}$ \\
Discrete: $65 \mathrm{~W}$
\end{tabular} \\
\hline Ethernet & Gigabit Ethernet \\
\hline
\end{tabular}

\subsection{Software yang Digunakan}

\subsubsection{U2000}

Adalah aplikasi yang berbasis Graphical User Interface (GUI) yang berfungsi untuk memonitoring jaringan, melakukan maintenance dan untuk melakukan konfigurasi secara grafik. Dalam hal ini konfigurasi yang dilakukan dalam U2000 adalah melakukan adding ONT dan konfigurasi profile untuk IPTV.
Aplikasi yang berfungsi untuk melakukan konfigurasi pada OLT dengan basis command line atau text. Dalam hal ini konfigurasi yang dilakukan adalah melakukan konfigurasi layanan multicast.

\subsubsection{Video LAN Client (VLC)}

Video LAN Client (VLC) adalah salah satu aplikasi yang dapat digunakan untuk melakukan video streaming, baik digunakan sebagai server (yang mengirim) ataupun digunakan sebagai client (yang menerima). VLC ini dapat mengkompresi dan dekompresi data audio maupun video dari beberapa media input dan mampu menunjukan hasil streaming dengan kualitas yang sama dengan aslinya.

\subsubsection{MediaInfo}

MediaInfo merupakan aplikasi untuk menampilkan data teknis untuk file Video dan audio, dengan menggunakan aplikasi ini kita bisa mengetahui datadata teknis pada suatu video atau audio. Khusus nya dalam penelitian yang akan dilakukan oleh penulis, diamana dalam penelitian ini akan menggunakan sebuah video sebagai content streaming, yang dimana penulis membutuhkan informasi seperti resolusi, bit rate dll.

\subsubsection{Bandwidth Monitor}

Bandwidth Monitor adalah aplikasi untuk memonitor penggunaan bandwidth melalui komputer yang di install, bandwidth monitor ini menampilkan kecepatan download dan upload dalam bentuk grafik dan angka secara real-time. Bandwidth monitor sangat dibutuhkan dalam penelitian yang dilakukan penulis, karena sangat membantu untuk memperoleh data pendistribusian bandwidth dari server terhadap client maupum bandwidth yang diterima oleh client.

\subsection{Flowchart Pengujian}

Dalam pengujian multicast ini ada beberapa tahapan yang perlu dilakukan, secara garis besar nya dijelaskan pada flowchart dibawah ini.

\subsubsection{SecureCRT}




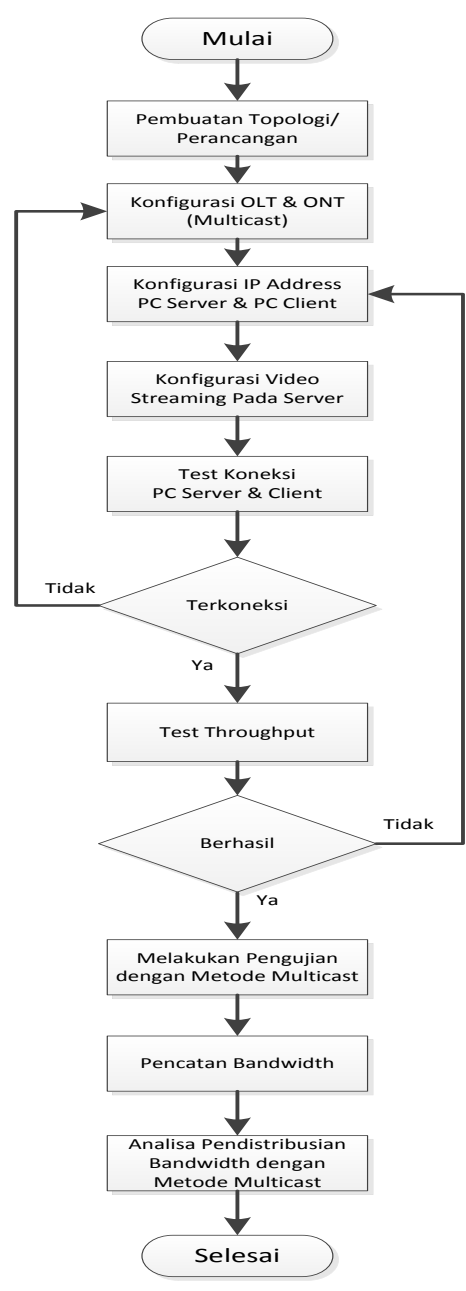

Gambar 5. Flowchart Pengujian

\subsection{Metode Pengujian}

Metode pengujian yang dilakukan adalah untuk mengetahuai penggunaan bandwidth atau pendistribusian bandwidth pada saat video streaming berlanjut. Sebelum melakukan streaming PC Client harus menginstall Video LAN Client (VLC) sebagai aplikasi yang digunakan untuk melakukan pengujian Video Streaming. Dalam pengujian ini menggunakan video dengan kualitas 360pixel, 480pixel dan 720pixel, dan disetiap kualitas video yang di uji akan dilakukan dua kali pengujian yang pertama, server melakukan stream video dan akan di akses oleh 1 PC Client, yang kedua server akan melakukan stream video dan akan di akses oleh 3 PC Client dengan masing masing waktu \pm 2 menit. Tujuannya adalah untuk mengetahui kebutuhan bandwidth yang dibutuhkan untuk setiap kualitas video yang di akan di deliver ke tiap client dengan menggunakan metode Unicast dan Multicast, dan untuk mengetahui pengunaan bandwidth ketika vidio tersebut di akses oleh 1 PC Client dan 3 PC Client.

\subsubsection{Skenario Pengujian Multicast}

Untuk melakukan broadcasting video pada VLC Server, didalam pengujian multicast ini menggunakan protocol User Datagram Protocol (UDP) dan IP Address yang digunakan dalam pengujian ini adalah 10.10.0.128/28. Setalah itu Setting IP Address pada PC Server dengan IP address 10.10.0.129, dan untuk PC Client 1 menggunakan IP address 10.10.0.137, PC Client 2 menggunalkan IP Address 10.10.0.138 dan PC Client 3 menggunakan IP Address 10.10.0.139. Pada setiap client menggunakan gateway 10.10.0.129 dengan subnet mask 255.255.255.240.

Setelah dilakukan setting IP Address pada Server dan Client, maka langkah selanjutnya adalah melakukan test koneksi antara Server dengan Client maupun sebalik nya dengan menggunakan printah Ping pada command prompt untuk memastikan koneksi antara server dan client kemudian capture hasil nya.

\subsubsection{Pengujian Video 360pixel}

1. PC Server melakukan stream video dengan kualitas 360pixel menggunakan protokol User Datagram Protocol (UDP) dan IP Address 239.255.0.1 port 1234 dengan 1 PC Client yang mengakses, dan hasil pengujian di capture.

2. PC Server melakukan stream video dengan kualitas 360pixel menggunakan protokol User Datagram Protocol (UDP) dan IP Address 239.255.0.1 port 1234 dengan 3 PC Client yang mengakses, dan hasil pengujian di capture.

\subsubsection{Pengujian Video 480pixel}

1. PC Server melakukan stream video dengan kualitas 480pixel menggunakan protokol User Datagram Protocol (UDP) dan IP Address 239.255.0.2 port 1234 dengan 1 PC Client yang mengakses, dan hasil pengujian di capture.

2. PC Server melakukan stream video dengan kualitas 480pixel menggunakan protokol User Datagram Protocol (UDP) dan IP Address 239.255.0.2 port 1234 dengan 3 PC Client yang mengakses, dan hasil pengujian di capture.

\subsubsection{Pengujian Video 720pixel}

1. PC Server melakukan stream video dengan kualitas 720pixel menggunakan protokol User Datagram Protocol (UDP) dan IP Address 239.255.0.3 port 1234 dengan 1 PC Client yang mengakses, dan hasil pengujian di capture. 
2. PC Server melakukan stream video dengan kualitas 720pixel menggunakan protokol User Datagram Protocol (UDP) dan IP Address 239.255.0.3 port 1234 dengan 3 PC Client yang mengakses, dan hasil pengujian di capture.

\subsubsection{Skenario Pengujian Unicast}

Untuk langkah pengujian sama seperti Multicast, dan perbedaan terletak pada protokol yang digunakan yaitu, protokol Real Time Streaming Protocol (RTSP). Dan pada unicast IP address yang digunakan untuk akses pada client menggunakan IP server itu sendiri dengan menambahkan path seperti contoh berikut, 10.10.0.128:8554/UnicastNandi.

\section{HASIL DAN PEMBAHASAN}

\subsection{Pengujian Vidoe Streaming Multicast}

Dalam pengujian multicast ada bebera skenario yang dilakukan oleh penulis diantaranya, skenario pertama dilakukan pengetesan dengan kualitas video 360p dengan 1 Client yang mengaksess dan 3 Client yang mengaksess, skenario kedua adalah melakukan pengetesan dengan kualitas video 480p dengan 1 Client yang mengaksess dan 3 Client yang mengaksess dan skenario ketiga yaitu menggunakan kualitas video 720p. tujuan dilakukan nya skenario seperti yang di atas dijelaskan adalah untuk mengetahuai seberapa besar bandwidth yang di deliver oleh server untuk setiap kualitas video yang di akses oleh 1 client dan ketika di akses oleh 3 client.

\subsubsection{Skenario 1 Pengujian Video 360p}

Hal yang pertama adalah mengetahui detail video yang akan diguanakan dalam pengujian dengan menggunakan aplikasi MediaInfo diantaranya informasi kualitas video, Bit rate dll.

Langkah selanjutnya adalah melakukan distribusi video menggunakan aplikasi VLC Media Player dari PC Server dan nantinya akan di akses oleh 1 Client kemudian akan di akses oleh 3 Client, hal ini dilakukan karena untuk membandingkan pendtribusian bandwidth ketika yang mengakses 1 client dan 3 client dengan cara sebagai berikut.

1. Buka aplikasi VLC Media Player, pilih Menu > Media > Open Multiple Files, seperti gambar dibawah

2. Setelah itu pilih menu Add dan pilih video yang akan di stream, kemudian pilih menu Stream pada drop down Play.
3. Pada option New destination Pilih UDP (legacy) sebagai protokol yang digunakan untuk multicast.

4. Langkah berikut nya menambahkan IP address untuk IP multicast atau untuk program yang akan di broadcast, dalam pengujian ini menggunakan video dengan kualitas 360p dengan IP address 239.255.0.1 dan untuk port diisikan default saja, kemudian klik next.

5. Selanjutnya berikan tanda centang pada Stream all elementary streams, kemudian klik tombol Stream.

Setelah selesai melakukan video stream pada PC Server, maka langkah selanjutnya adalah melakukan akses video yang sudah di stream oleh PC Server. Adpun langkah - langkah sebagai berikut:

1. Buka aplikasi VLC Media Player, pilih Menu > Media > Open Network Stream, seperti gambar dibawah

2. Kemudiam isikan url udp://239.255.0.1:1234, artinya protokol yang digunakan adalah protokol UDP, dan IP address yang telah di stream pada PC Server untuk video dengan kualitas 360p dan port stream menggunakan 1234, kemudian klik tombol play.

Dengan melakukan hal di atas maka hasil pengujian dapat dilihat pada tabel dan gambar dibawah.

Tabel 5. Pengujian Video 360p Multicast

\begin{tabular}{|l|c|c|c|c|}
\hline \multicolumn{5}{|c|}{ Sekenario 1 Pengujlan Video 360p } \\
\hline Skenario Test & Device & $\begin{array}{c}\text { Maximal } \\
\text { Rate (Kbps) }\end{array}$ & $\begin{array}{c}\text { Minimum } \\
\text { Rate (Kbps) }\end{array}$ & $\begin{array}{c}\text { Average } \\
\text { (Kbps) }\end{array}$ \\
\hline \multirow{2}{*}{ Akses 1 Client } & PC Server & 2191.36 & 272.7 & 1024 \\
\cline { 2 - 5 } & PC Client 1 & 2549.76 & 239.7 & 967.3 \\
\hline \multirow{3}{*}{ Akses 3 Client } & PC Server & 2211.84 & 276.0 & 999.6 \\
\cline { 2 - 5 } & PC Client 1 & 2201.6 & 218 & 954.6 \\
\cline { 2 - 5 } & PC Client 2 & 2334.72 & 207.6 & 925.1 \\
\cline { 2 - 5 } & PC Client 3 & 2088.96 & 211.3 & 930.5 \\
\hline
\end{tabular}

\subsubsection{Skenario 2 Pengujian Video 480p}

Dalam skeraio ini langkah yang dilakukan sama seperti skenario 1 , namun perbedaan nya adalah pada kualitas video yang akan dilakukan pengujian yanitu, kualitas video 480oixel. Dan untuk hasil nya dapat dilihat pada tabel dan gambar berikut.

Tabel 6. Pengujian Video 480p Multicast 


\begin{tabular}{|l|c|c|c|c|}
\hline \multicolumn{5}{|c|}{ Sekenario 2 Penzujian Video 480p } \\
\hline Skenario Test & Device & $\begin{array}{c}\text { Maximal } \\
\text { Rate (Kbps) }\end{array}$ & $\begin{array}{c}\text { Minimum } \\
\text { Rate (Kbps) }\end{array}$ & $\begin{array}{c}\text { Average } \\
\text { (Kbps) }\end{array}$ \\
\hline \multirow{2}{*}{ Akses 1 Client } & PC Server & 3686.40 & 196.5 & 1443.84 \\
\cline { 2 - 6 } & PC Client 1 & 3082.24 & 186.2 & 1402.89 \\
\hline \multirow{3}{*}{ Akses 3 Client } & PC Server & 3481.60 & 272.7 & 1495.04 \\
\cline { 2 - 6 } & PC Client 1 & 3297.28 & 301 & 1546.24 \\
\cline { 2 - 6 } & PC Client 2 & 3102.72 & 240.3 & 1505.28 \\
\cline { 2 - 5 } & PC Client 3 & 3031.04 & 196.1 & 1464.32 \\
\hline
\end{tabular}

\subsubsection{Skenario 3 Pengujian Video 720p}

Dalam skenario ke 3 ini video yang akan digunakan untuk melakukan penelitian adalah video yang berkualitas 720pixel. Dan hasil yang di dapat bisa dilihat pada tabel dibawah.

Tabel 7. Pengujian Video 720p Multicast

\begin{tabular}{|l|c|c|c|c|}
\hline \multicolumn{5}{|c|}{ Sekenario 3 Pengujlan Video 720p } \\
\hline \multirow{2}{*}{ Skenario Test } & Device & $\begin{array}{c}\text { Maximal } \\
\text { Rate (Kbps) }\end{array}$ & $\begin{array}{c}\text { Minimum } \\
\text { Rate (Kbps) }\end{array}$ & $\begin{array}{c}\text { Average } \\
\text { (Kbps) }\end{array}$ \\
\hline \multirow{2}{*}{ Akses 1 Client } & PC Server & 6666.24 & 351.7 & 2539.52 \\
\cline { 2 - 5 } & PC Client 1 & 6686.72 & 217.9 & 2396.16 \\
\hline \multirow{3}{*}{ Akses 3 Client } & PC Server & 4464.64 & 274 & 2437.12 \\
\cline { 2 - 5 } & PC Client 1 & 4341.76 & 382.9 & 2590.72 \\
\cline { 2 - 5 } & PC Client 2 & 4648.96 & 350.7 & 2539.52 \\
\cline { 2 - 5 } & PC Client 3 & 4526.08 & 196.8 & 2426.88 \\
\hline
\end{tabular}

\subsection{Pengujian Video Streaming Unicast}

Yang berbeda dalam pengujian video streaming dengan metode unicast adalah protokol yang digunakan, yaitu menggunakan protokol Real Time Streaming Protocol (RTSP). Untuk skenario yang digunakan sama seperti melakukan pengujian dengan metode multicast, dimana ada 3 skenario yang akan di lakukan yaitu, skenario pertama dilakukan pengetesan dengan kualitas video 360p dengan 1 Client yang mengaksess dan 3 Client yang mengaksess, skenario kedua adalah melakukan pengetesan dengan kualitas video 480p dengan 1 Client yang mengaksess dan 3 Client yang mengaksess dan skenario ketiga yaitu menggunakan kualitas video 720 p.

\subsubsection{Skenario 1 Pengujian Video 360p}

Pada skenario ke 1 dapat dilihat hasil pengujian pada tabel dibwah.

Tabel 8. Pengujian Video 360p Unicast

\begin{tabular}{|c|l|c|c|c|}
\hline \multicolumn{5}{|c|}{ Sekenario 1 Pengujian Video 360p } \\
\hline $\begin{array}{c}\text { Skenario } \\
\text { Test }\end{array}$ & Device & $\begin{array}{c}\text { Maximal } \\
\text { Rate (Kbps) }\end{array}$ & $\begin{array}{c}\text { Minimum } \\
\text { Rate (Kbps) }\end{array}$ & $\begin{array}{c}\text { Average } \\
\text { (Kbps) }\end{array}$ \\
\hline \multirow{2}{*}{$\begin{array}{c}\text { Akses 1 } \\
\text { Client }\end{array}$} & PC Server & 2027.52 & 193.5 & 902.3 \\
\cline { 2 - 5 } & PC Client 1 & 2058.24 & 206.9 & 957.8 \\
\hline \multirow{3}{*}{$\begin{array}{c}\text { Akses 3 } \\
\text { Client }\end{array}$} & PC Server & 6031.36 & 617.5 & 2908.16 \\
\cline { 2 - 5 } & PC Client 1 & 2027.52 & 195.2 & 899 \\
\cline { 2 - 5 } & PC Client 2 & 2170.88 & 182 & 915.4 \\
\cline { 2 - 5 } & PC Client 3 & 2181.12 & 181 & 919.3 \\
\hline
\end{tabular}

\subsubsection{Skenario 2 Pengujian Video 480p}

Pada skenario ke 2 data yang di dapat bisa dilihat pada tabel dibawah.
Tabel 9. Pengujian Video 480p Unicast

\begin{tabular}{|c|c|c|c|c|}
\hline \multicolumn{5}{|c|}{ Sekenario 2 Pengujian Video 480p } \\
\hline $\begin{array}{c}\text { Skenario } \\
\text { Test }\end{array}$ & Device & $\begin{array}{c}\text { Maximal } \\
\text { Rate (Kbps) }\end{array}$ & $\begin{array}{c}\text { Minimum } \\
\text { Rate (Kbps) }\end{array}$ & $\begin{array}{c}\text { Average } \\
\text { (Kbps) }\end{array}$ \\
\hline \multirow{2}{*}{$\begin{array}{c}\text { Akses 1 } \\
\text { Client }\end{array}$} & PC Server & 2580.48 & 211.70 & 1249.28 \\
\cline { 2 - 5 } & PC Client 1 & 2447.36 & 239.50 & 1320.96 \\
\hline \multirow{3}{*}{$\begin{array}{c}\text { Akses 3 } 3 \\
\text { Client }\end{array}$} & PC Server & 9441.28 & 522.80 & 3850.24 \\
\cline { 2 - 5 } & PC Client 1 & 2785.28 & 168.50 & 1331.20 \\
\cline { 2 - 5 } & PC Client 2 & 3051.52 & 161.60 & 1300.48 \\
\cline { 2 - 5 } & PC Client 3 & 3123.20 & 160.40 & 1280.00 \\
\hline
\end{tabular}

\subsubsection{Skenario 3 Pengujian Video 720p}

Skenario ke 3 data yang di dapat bisa dilihat pada tabel berikut.

Tabel 10. Pengujian Video 720p Unicast

\begin{tabular}{|c|c|c|c|c|}
\hline \multicolumn{5}{|c|}{ Sekenario 3 Pengujian Video 720p } \\
\hline $\begin{array}{c}\text { Skenario } \\
\text { Test }\end{array}$ & Device & $\begin{array}{c}\text { Maximal } \\
\text { Rate (Kbps) }\end{array}$ & $\begin{array}{c}\text { Minimum } \\
\text { Rate (Kbps) }\end{array}$ & $\begin{array}{c}\text { Average } \\
\text { (Kbps) }\end{array}$ \\
\hline Akses 1 & PC Server & 289792.00 & 221.40 & 1812.48 \\
\cline { 2 - 5 } Client & PC Client 1 & 2723.84 & 186.90 & 1771.52 \\
\hline \multirow{3}{*}{$\begin{array}{c}\text { Akses 3 } \\
\text { Client }\end{array}$} & PC Server & 2908.16 & 199.80 & 7229.44 \\
\cline { 2 - 5 } & PC Client 1 & 4106.24 & 264.30 & 2396.16 \\
\cline { 2 - 5 } & PC Client 2 & 4147.20 & 225.90 & 2437.12 \\
\cline { 2 - 5 } & PC Client 3 & 4075.52 & 299.10 & 2478.08 \\
\hline
\end{tabular}

\subsection{Analisis Hasil Pengujian dengan Metode} Multicast

Setelah dilakukan pengujian maka dapat terlihat perbendaan bandwidth yang di distribusikan oleh server terhadap client dengan metode multicast dan dengan beberapa skenario pengujian yaitu dengan menggunakan kualitas video yang berbeda, diantara nya video yang berkualitas 360pixel, 480pixel dan 720pixel dengan source video yang sama yang berjudul Mazinger Z: Infinity dan skenariao dimana pada setiap video yang di didistribusikan oleh server masing-masing akan di akses oleh 1 client dan 3 client secara bergantian.

Dengan skenario seperti diatas maka dapat terlihat perbedaan bandwidth yang di butuhkan oleh setiap kualitas video ketika di akses oleh 1 client dan ketika di akses 3 client. Dengan metode multicast maka pendistribusian video yang berlangsung yaitu satu pengiriman untuk banyak penerima atau biasa disebut one to many, dan berikut grafik untuk pengujian pendistribusian bandwidth dengan metode multicast. 


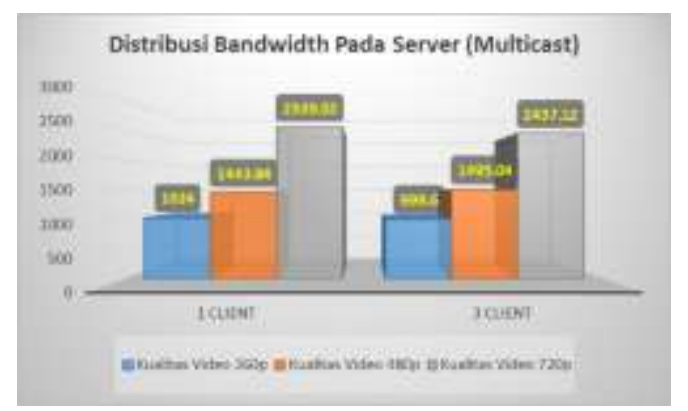

Gambar 6. Grafik Banwidth Pada Server (Multicast)

Grafik diatas merukapan data bandwidth yang di distribusikan oleh server dengan nilai average atau rata-rata bandwidth yang kirimkan oleh server untuk setiap kualitas video dan dengan jumlah client yang meng-akses 1 sampai dengan 3 client.

Dalam grafik dapat dilihat kebutuhan bandwidth ketika 1 client yang meng-akses dengan kualitas video 360pixel membutuhkan bandwidth sebesar $1024 \mathrm{kbps}$, untuk video yang berkualitas 480pixel membutuhkan bandwidth sebesar 1443.84 kbps dan untuk video yang berkualitas 720pixel membutuhkan bandwidth sebesar 2539.52 kbps.

Kemudian kebutuhan bandwidth ketika 3 client yang meng-akses pada video yang berkualitas 360pixel membutuhkan bandwidth sebesar $999.6 \mathrm{kbps}$, untuk video yang berukuran 480pixel membutuhkan bandwidth sebesar 1495.04 kbps sedangkan untuk video yang berkualitas 720pixel membutuhkan bandwidth $2437.12 \mathrm{kbps}$.

Jika melihat hasil yang ada dalam pengujian multicast untuk semua kualitas video yang di broadcast oleh server dan di akses oleh 1 client dan 3 client, maka kebutuhan bandwidth tidak meningkat dan cenderung tetap pada ukuran bitrate video tersebut. Jadi untuk multicast ini seberapa banyak pun jumlah client yang akan meng-akses tidak akan meninggkatkan kebutuhan bandwidth pada server. Karena secara teoripun dalam multicast cukup mengirimkan satu aliran paket data saja untuk satu grup berisi $\mathrm{n}$ yang akan di terima.

\subsection{Analisis Hasil Pengujian dengan Metode Unicast}

Konsep dalam unicast tentu berbeda dengan konsep multicast, dalam unicast untuk satu paket yang dikirimkan oleh server makan hanya untuk satu penerima atau biasa disebut one to one. Jadi dalam metode unicast ini bandwidth akan meningkat seiring bertambahnya jumlah client yang melakukan streaming atau menerima data, pada grafik di bawah bisa dilihat untuk hasil pengujiannya.

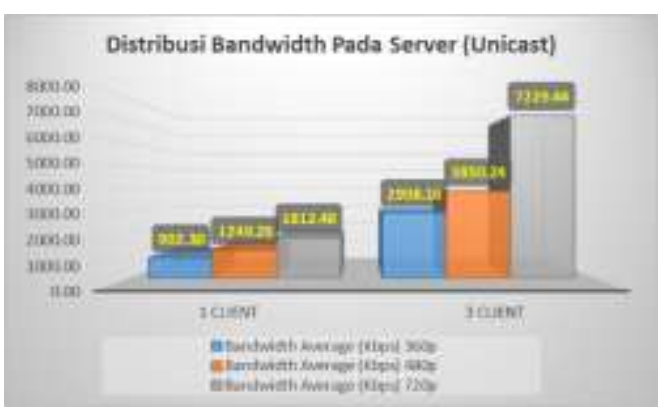

Gambar 6. Grafik Banwidth Pada Server (Unicast) Dalam grafik dapat dilihat hasil dari pengujuan dengan 1 client yang meng-akses pada kualitas video 360pixel membutuhkan 902.30 kbps bandwidth, untuk kualitas video 480pixel membutuhkan bandwidth $1249.28 \mathrm{kbps}$ dan untuk video yang berkualitas 720pixel bandwidth yang dibutuhkan sebesar $1812.48 \mathrm{kbps}$.

Sedangkan bandwidth yang dibutuhkan untuk 3 client yang meng-akses dalam metode unicast pada video berkualitas 360pixel membutuhkan bandwidth 2908.16 kbps, untuk video berkualitas 480pixel membutuhkan bandwidth 3850.24 kbps sedengkan untuk video berkualitas 720pixel membutuhkan bandwidth 7229.44 kbps.

Dengan hasil diatas terlihat jelas untuk peningkatan bandwidth yang dikirimkan oleh server ketika di akses oleh 3 client yaitu mencapai 3 kali lipat nya. Seperti yang sudah dijelaskan di atas untuk motode unicast ini bandwidth atau trafik Akan meningkat seiring bertambahnya jumlah client yang meng-akses.

\section{KESIMPULAN}

Setelah melakukan penelitian mengenai "Analisis Pendistribusian Bandwidth pada Video Streaming dengan Metode Unicast dan Multicast pada Teknologi Gigabit Passive Optical Network" dengan beberapa skenario pengujian, maka dapat di simpulkan sebagai berikut:

1. Bandwidth yang di distribusikan oleh server dengan menggunakan metode multicast menunjukan penghematan bandwidth yang signifikan dibandingkan dengan metode unicast. Peningkatan bandwidth yang sangat signifikan antara multicast dan unicast dapat dilihat pada hasil ketika video yang di broadcast oleh server di akses secara bersamaan oleh 3 client, dengan hasil pengujian menggunakan metode multicast bandwidth rata-rata yang di dibutuhkan pada video berkualitas 360pixel ialah 999.6 kbps sedangkan pada metode unicast dengan kualitas video yang sama ialah 2908.16 Kbps.

2. Kenaikan atau kebutuhan bandwidth meningkat pada kualitas video yang lebih tinggi, baik pada metode multicast ataupun unicast, hasil rata-rata 
yang didapat untuk pengujian setiap kualitas video adalah sebagai berikut. Video berkualitas 360pixel 1024 kbps, video berkualitas 480pixel 1443.84 dan untuk video berkualitas 720pixel sebesar 2539.52 kbps..

\section{REFERENSI}

Agil S, AC. (2010). Cara Cepat Bikin Live TV di Blog dan Website, CV. Andi Offset, Yogyakarta http://www.aldhinya.com/2016/07/.

(2018). pengertian-dan-perbedaan-bandwidth-danthroughput.html, di unduh pada 17 March 2018 4:48. http://www.asus87.com/2016/08/.(2017). teknologijaringan-gpon-dan-gepon/, di unduh pada 15 Desember 2017 17:22. 